\title{
THE EFFECT OF E-PERFORMANCE ON ORGANIZATIONAL PERFORMANCE MEDIATED BY EMPLOYEE PERFORMANCE, DISCIPLINE AND MOTIVATION : STUDY IN GOVERNMENT OF BANDA ACEH CITY
}

\author{
Rekawani, Permana Honeyta Lubis and Sorayanti Utami \\ Department of Management, Universitas Syiah Kuala, Indonesia \\ http://doi.org/10.35409/IJBMER.2020.3165
}

\begin{abstract}
This study is to verify the effect of the effect of e-performance on organizational performance mediated by employee performance, discipline and motivation. The object is the government of banda aceh city. The population is the all civil servant (employee) of Government of Banda Aceh City, as much as 4.398 , and the proportional random sampling is used to determined the sample, and it provides as much as 180 respondents based on the grade of each employee.. The data is collected by using questionnaires, with the answer choice uses the likert scale. Structural Equation Modeling (SEM) is used to analyze the data.The result proves that e-performance affects employee performance, e-performance affects employee discipline, e-performance affects work motivation, employee performance affects organizational performance, work discipline will affects organizational performance, and work motivation affects organizational performance of the Banda Aceh Secretariat. These all findings prove the previous theories to be the update ones, and the model contributes to the realm of science and the practical implications, especially in the research object that is Banda Aceh Secretariat. The novelty originality lies in the integration of the causality theories from the previous, and its new object. The limitation resides in its scope and the variable amount.
\end{abstract}

Keyword: E-Performance, Employee Performance, Work Discipline, Work Motivation and Organizational Performance.

\section{INTRODUCTION}

The Banda Aceh Governmentis the organization that provides services to the public in this case the people of Banda Aceh City. Public services are included in one of the three tasks or role of the state according to Adam Smithin (Soepangat and Gaol, 1991), namely to uphold and maintain public institutions and their jobs, which can provide the highest degree of benefit to society. So that the public services provided by the Banda Aceh City Government are an indication of the success of the organization in providing services to the public.

The success of an organization is strongly influenced by the performance of individual employees. Every organization and company will always try to improve employee performance, with the hope that what the company's goals will be achieved. One of the ways taken by the company in improving the performance of its employees, for example through education, 


\section{International Journal of Business Management and Economic Review}

Vol. 3, No. 02; 2020

ISSN: 2581-4664

training, providing proper compensation, providing motivation, and creating a conducive work environment. Therefore the success or failure of an employee at work will be known if the organization concerned implements a performance appraisal system that is suitable and can be accepted by all employees or employees, such as the application of e-performance in the Banda Aceh City Government to assess the performance of its employees based on the work volume can be completed or carried out by the employee concerned within the allotted time. The development of e-performance applications was developed in order to facilitate all apparatuses in inputting activities / work and making Daily Work Reports (LKH). Besides this application is expected to be one of the supporting instruments for the leadership in making decisions related to the performance of employees, units and work units.

E-performance is one of the web-based applications used by the Banda Aceh City Government to analyze position needs, workload and organizational workload as a basis for calculating work performance and granting work incentives by referring to Permendagri No. 4 of 2005 concerning ANJAB and Permendagri No. 12 of 2008 concerning ABK. In the Analysis of Position (ANJAB) in the e-performance application can be accessed by the public, while in the analysis of workload (ABK) only used by the Banda Aceh City Government. Workload Analysis Section is used by employees to input daily work reports and is used by leaders to determine the performance of employees and work units / units. This application was developed to facilitate the apparatus in inputting activities / work and making a Daily Work Report (LKH). Besides this application is expected to be one of the supporting instruments for the leadership in making decisions related to the performance of employees, units and work units.

The e-peformance application system was developed based on Open Source (open code) using a programming language the PHP (Hypertext Preprocessor), while for the display interface used Flash and Jquery. For the database used My SQL and Web Server used Apache. The choice of application base using Open Source (open code) was because it is easy to learn and modify, so it does not depend on the developer.

Performance measurement is a portrait of the calculation of performance allowance payments in the Banda Aceh City Government. This application can be accessed through the website: performance. bandaacehkota.go.id. It takes an increase in employee performance in order to be able to carry out existing tasks as well as possible. Because of that work discipline factors have an influence and an important role in improving employee performance. When viewed in real terms, the discipline factor plays a very important role in the implementation of the daily tasks of employees. An employee who has a high level of discipline will continue to work well even without being monitored by superiors. A disciplined employee will not steal work time to do other things that have nothing to do with work. Likewise, employees who have discipline will obey the rules in the work environment with high awareness without any sense of coercion. In the end, employees who have high work discipline will have a good performance when compared to employees who are lazy because working time is used as well as possible to carry out work in accordance with the targets set.

Discipline is a starting point for any success in achieving an organization's goals. The application of discipline in an organization aims that all employees in the organization are willing to voluntarily comply with and obey every order that applies without coercion. Good work discipline can be seen from the high awareness of its employees in obeying and obeying all applicable rules and regulations, the amount of sense of responsibility for their respective duties, 


\section{International Journal of Business Management and Economic Review}

Vol. 3, No. 02; 2020

ISSN: 2581-4664

and increasing the efficiency and performance of their employees. Discipline itself is divided into two types, namely preventive discipline and corrective discipline. Preventive discipline is an action that seeks to encourage employees to comply with and obey existing regulations because of their own awareness, in other words more aimed at preventing employees from making mistakes and violations. While corrective discipline is an action in the form of giving sanctions to employees or in other words it is intended that employees do not repeat the mistakes that have been made. Employees who lack discipline will find it difficult to increase productivity and will be impossible to realize the achievement of the goals set by the company beforehand.

In addition to the above motivational factors are also important in improving employee performance. Motivation can be a driving force for someone to carry out an activity in order to get the best results. Therefore it is not surprising that employees who have high work motivation usually have high performance as well. For this reason, in addition to work discipline, it would be better if the employee's work motivation needs to be raised and improved so that employees can produce the best performance. Based on the description above, it can be seen how important the role of work discipline factors and work motivation is in improving employee performance.

While the performance is the work that can be achieved by a person or group of people in an organization, in accordance with their respective authorities and responsibilities in an effort to achieve the objectives of the organization concerned legally, does not violate the law and in accordance with morals and ethics. So the performance is important for the company or organization as well as on the part of the employee itself. Employee performance is influenced by several factors both related to the workforce itself and those related to the company or organization's environment.

The phenomena relating to the performance of the Banda Aceh City Government can also be seen from the service procedures that are not in line with community expectations, service requirements are still complicated, disciplinary officers are not yet suitable, officer responsibilities are still lacking in providing services, speed of service not in accordance with expectations, politeness and friendliness of officers, certainty of service costs, certainty of service schedules, environmental security and security of services. which is considered still not good.

Seeing the phenomena that employee discipline is very low, there are some employees who are coming only to go for morning rite and after that the employee sit and relax at the stall or return home,they have no motivation at all to work because theydo not know what they must do. When in fact every employee already has a main tasks and functions that employees must understand and carry out.

\section{LITERATURE REVIEW}

\section{Organizational Performance}

Organizational performance is an indicator of the level of achievement that can be achieved and reflects the success of an organization, and is the result achieved from the behavior of organizational members. Performance can also be said as a result (output) of a particular process carried out by all components of the organization against certain sources used (input). Furthermore, performance is also the result of a series of process activities carried out to achieve certain organizational goals. For an organization, performance is the result of collaborative activities among members or components of the organization in order to realize organizational 


\section{International Journal of Business Management and Economic Review}

Vol. 3, No. 02; 2020

ISSN: 2581-4664

goals.

The organization is a structure of the division of labor and structure of work relations between groups of people holding positions that work in a certain way to jointly achieve certain goals. According to (Winardi, 2006) the organization is the structure of the division of labor and the structure of work relations between a group of people holding positions that work together to achieve certain objectives.

Organization is any form of alliance between two or more people who work together and are formally bound in the context of achieving a goal that has been determined in a bond where there is a person, some people called superiors and one / a group of people called subordinates. (Winardi, 2006)

An organization is a group of people (two or more) who are formally united in a partnership to achieve the stated goals. An organization is formed because it has the basis and objectives to be achieved. According to (Money, 1996), organization is a form of human union to achieve a common goal. But we need to understand that the basis of the organization, not "who" but "what" means that what matters is not who is the person who will hold the organization, but the "what" is the task of the organization.

An organization can be formed because it is influenced by several aspects such as the unification of vision and mission and the same goals with the realization of the existence of a group of people towards society. Organizations that are considered good are organizations that can be recognized by the surrounding community, because they contribute such as the taking of human resources in the community as members so as to reduce unemployment.

"Organizational performance is the totality of the work achieved by an organization achieving the goals of the organization means that, the performance of an organization can be seen from the degree to which the organization can achieve goals based on the goals set previously". (Surjadi, 2009). According to (Wirawan, 2007) Organizational performance is something that has been achieved by the organization within a certain period of time, both related to inputs, outputs, outcomes, benefits, and impacts.

\section{Employee Performance}

According to (Wungu and Brotoharsojo, 2003) that "Quality (quality) is any form of unit of measurement related to the quality or quality of work results and expressed in numerical sizes or which can be matched with numbers". Meanwhile, according to (Wilson and Heyel, 1987) said that "Quality of work (quality of work) shows the extent to which the quality of an employee in carrying out his duties include accuracy, completeness, and neatness".

From the opinions above, it is clear that the quality of work can be measured through accuracy, completeness, and neatness. What is meant by accuracy is accuracy in carrying out tasks and work, meaning that there is a match between the activity plan with the fault or the objectives set. What is meant by completeness is completeness in carrying out its duties. What is meant by neatness is neatness in carrying out its tasks and work.

Then according to (Ilyas, 2011), the concept of performance is an abbreviation of work energy kinetics which in English is performance. Performance is the output produced by functions or individuals on a particular job or profession. Performance that is often also referred to as work performance is the result of work in quantity and quality achieved by someone in carrying out tasks according to the responsibilities given at a certain time. (Swanburg, Ester and Samba, 


\section{International Journal of Business Management and Economic Review}

Vol. 3, No. 02; 2020

ISSN: 2581-4664

2000) defines individual performance as individual work performance that is set based on standards or criteria set by an organization.

Based on the above understanding, it can be concluded that performance or what is often referred to as work performance or job performance is the quality and quantity of an individual's work output in a particular activity and according to the measurement applicable to the work in question. This measure is determined by the organization determined as a target in one period.

\section{Work Discipline}

Work discipline is an indispensable attitude and gets attention in every job carried out by everyone in an effort to improve performance in order to achieve organizational goals. Etymologically the discipline comes from the Latin word "disipel" which means follower. In its development the word has changed to "discipline" which means compliance or relating to the order. And the word discipline has developed following the progress of science, and many different disciplinary understandings among experts are the opinions of other experts.

Discipline is a serious obedience that is supported by awareness to carry out their duties and obligations and behave that should apply in certain environments. While the notion of work is the act of carrying out activities aimed at getting results (Toha, 2017).

According to (Siagian, 2012)the discipline is every individual and also a group that guarantees compliance with orders and takes the initiative to take an action that is necessary if there is no order.

Then another opinion was raised by (Mangkunegara, 2013) which stated that employee work discipline is the nature of an employee who consciously complies with certain organizational rules and regulations. Work discipline greatly affects the performance of employees and the company. Work discipline should be seen as forms of training for employees in implementing company rules. The more discipline the higher employee productivity and company performance.

Work discipline is a feeling of being obedient and obedient to the values that are trusted, including doing certain jobs that are felt to be a responsibility when connected with the duties and obligations as well as prohibitions for civil servants. Work discipline is also the most important function of Resource Management, because the better employee discipline the higher job performance can be achieved. Without good employee discipline, it is difficult for the organization or company to achieve optimal results.

Good discipline reflects the magnitude of one's sense of responsibility for the tasks given to him. This can motivate or encourage morale and the realization of organizational or agency goals. Therefore, every leader or supervisor must always strive so that his subordinates have good discipline. A leader or superior is said to be effective in his leadership, if his subordinates have good discipline.

\section{Work Motivation}

Motivationis a condition that is needed by every one. It is needed every day to run a life, help others, lead a group of people and to achieve the desired goals(Harris, Harvey and Kacmar, 2009). Motivation comes from the word "movere" (Latin), which means pushing or moving(Wirawan, 2007). Motivation is all the power that is in a person who gives power, direction and maintain the behavior in question. In ourdailylives, motivationis defined as the 


\section{International Journal of Business Management and Economic Review}

Vol. 3, No. 02; 2020

ISSN: 2581-4664

whole process of giving encouragement or stimulation to employees, so they are willing to work willingly without feeling forced(Wirawan, 2007).

Motivationis a tendency to indulge, starting from the drive within (drive) and endingwitha djustment, self-adjustment is said to satisfy the motive (Shiri, Akhavan and Geramian, 2012). Meanwhile, accordingto(Rivai and Sagala, 2014) "Motivationis a series of attitudes and values that influence individuals to achieve specificthings in accordance with individual goals".

Further more, (Robbins and Judge, 2012) defines motivation as a willingness to spend a highlevel of effort towards organizational goals that are conditioned by the ability of the effort to meet an individual' sneeds.

\section{E-Performance}

Performance is an illustration of the achievement of the implementation of a program activity or policy in realizing the goals, objectives, mission and vision of the organization. List of what you want to achieve contained in strategic planning (strategy planning), an organization. In general, performance is an achievement to be achieved by an organization within a certain period (Bastian, 2007). Banda Aceh City Government made the application of Electronic performance or e-performance is one of the web-based applications to analyze the needs of positions, workloads and workloads of organizational units / work units as a basis for calculating work performance and granting work incentives by referring to Minister of Home Affairs Regulation No. 4 of 2005 concerning ANJAB and Permendagri No. 12 of 2008 concerning ABK. The purpose of e-performance is to improve the performance of civil servants and organizations; Organizing and perfecting the organization; Conduct an assessment of the work performance of civil servants and organizations; Give a sense of justice and improve the welfare of civil servants; Encourage the creation of healthy work competition among civil servants; Improve HR competencies and positions held by PNS; and Foster creativity and innovation in civil servant work (Banda Aceh Mayor Regulation Number 38 of 2012 Article 5).

E-performance is one of the web-based applications for analyzing job needs, workload and workload units or organizational work units as a basis for calculating work performance and providing work incentives (Putri, Arfan and Basri, 2014). Previous employee performance measurements were carried out using the DP3 (List of Work Implementation Assessments), along with the times, the assessment of civil servant work performance with DP3 is no longer relevant. The government found a solution to this problem by issuing Government Regulation No. 46 of 2011 concerning Performance Evaluation of Civil Servants Work that took effect on January $1^{\text {st }}$, 2014. The current employee appraisal has changed from previously using DP3 format to SKP format. E-performance is an example of the application of human resource accounting theories summarized in a web-based application. E-performance can measure, identify, deliver, assess, and award additional income.

\section{Previous Research Review}

Research conducted by (Miswar, Musnadi and Mahdani, 2015)proved that eperformance affects employee discipline, then the result also showed that e-performance affects employee work motivation, while employee work discipline also influences employee performance, employee work motivation affects employee performance and there is an indirect effect of e-performance on employee performance through discipline and work motivation in the 


\section{International Journal of Business Management and Economic Review}

Vol. 3, No. 02; 2020

ISSN: 2581-4664

Banda Aceh CityGovernment.

Research conducted by (Marzuki, Nasir and Sofyan, 2018) proved that to improve employee performance contributes significantly to improve organizational performance in improving the performance of the Regional Office of the DJP Aceh. Then (Oktavina, Nurdasila and Kesuma, 2018) proved that work motivation possessed by employees has an influence in improving employee performance at PT. Bank PermataTbk. Medan.

\section{Research Hypothesis}

From the discussion above, authors concludes the hypothesis that can be formulated in this research as follows.

H1 : e-performance affects employee performance

$\mathrm{H} 2$ : e-performance affects employee discipline

$\mathrm{H} 3$ : e-performance affects work motivation

$\mathrm{H} 4$ : employee performance affects organizational performance

H5 : work discipline will affects organizational performance

H6 : work motivation affects organizational performance

\section{RESEARCH METHOD}

This research is conducted at the Banda Aceh City Government. The variables are eperformance, employee performance, work discipline, work motivation and the performance, and the object is the Banda Aceh City Government.The population isall civil servant (employee) of Government of Banda Aceh City, as much as 4.398, and the proportional random sampling is used to determined the sample, and it provides as much as 180 respondents based on the grade of each employee. The data is collected by using questionnaires, with the answer choice uses the likert scale. Structural Equation Modeling (SEM) is used to analyze the data. The use of SEM allows researchers to examine relationships between complex variables to get a comprehensive picture of the whole model.According to (F. Hair Jr et al., 2014) SEM method is the development of path analysis and multiple regression which are both forms of multivariate analysis.

\section{RESULT}

\section{Confirmatory Factor Analysis (CFA) Test}

First test uses the confirmatory factor analysis method. This research model consists of 32 indicators that need to be tested the eligibility.The confirmatory factor analysis result for all constructs in this study is shown in the figure below. 
Vol. 3, No. 02; 2020

ISSN: 2581-4664

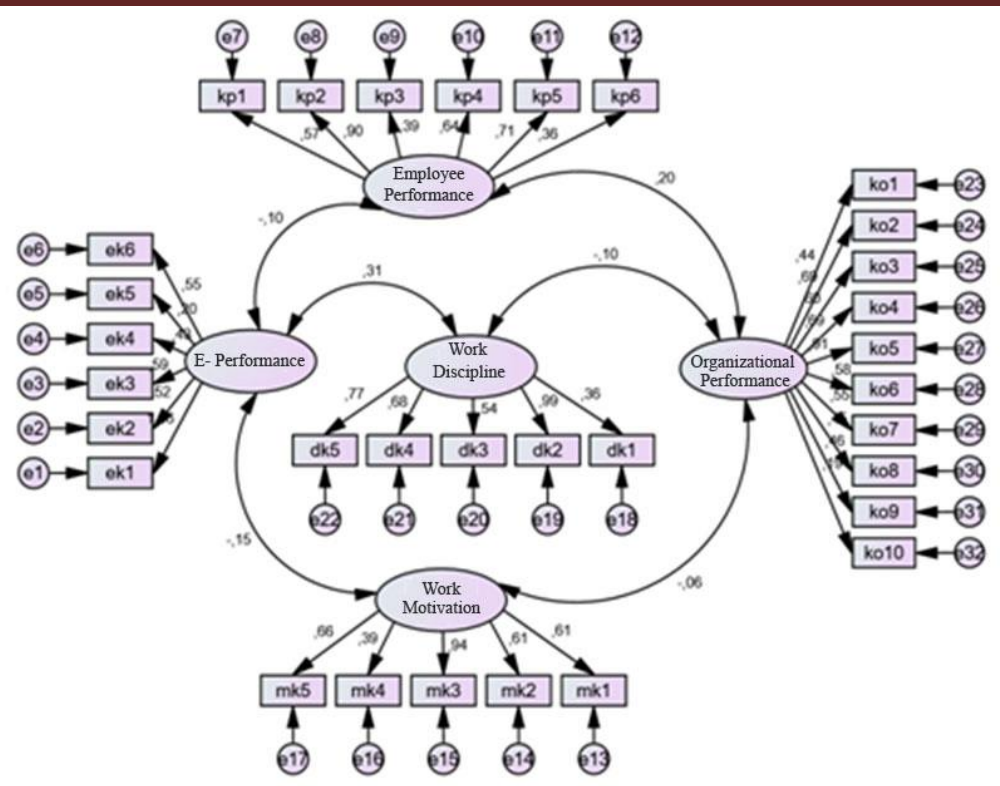

Figure 1. Confirmatory Factor Analysis

The loading factors that represent the contribution of each indicator to the variables they represent can be seen in the following table:

Table 1. Loading Factor Indicator For Variables

\begin{tabular}{|lll|l|}
\hline Kode & Arah & Indikator & Estimate \\
\hline ek1 & $<---$ & e-performance & 0.558 \\
ek2 & $<---$ & e-performance & 0.520 \\
ek3 & $<---$ & e-performance & 0.593 \\
ek4 & $<---$ & e-performance & 0.529 \\
ek5 & $<---$ & e-performance & 0.799 \\
ek6 & $<---$ & e-performance & 0.547 \\
kp1 & $<---$ & Performance employee & 0.568 \\
kp2 & $<---$ & Performance employee & 0.902 \\
kp3 & $<---$ & Performance employee & 0.587 \\
kp4 & $<---$ & Performance employee & 0.635 \\
kp5 & $<---$ & Performance employee & 0.708 \\
kp6 & $<---$ & Performance employee & 0.663 \\
mk1 & $<---$ & Work motivation & 0.608 \\
mk2 & $<---$ & Work motivation & 0.612 \\
mk3 & $<---$ & Work motivation & 0.936 \\
mk4 & $<---$ & Work motivation & 0.694 \\
mk5 & $<---$ & Work motivation & 0.657 \\
\hline
\end{tabular}




\section{International Journal of Business Management and Economic Review}

Vol. 3, No. 02; 2020

ISSN: 2581-4664

\begin{tabular}{|c|c|c|c|}
\hline Kode & Arah & Indikator & Estimate \\
\hline $\mathrm{dk} 1$ & $<---$ & Work dicipline & 0.658 \\
\hline $\mathrm{dk} 2$ & $<---$ & Work dicipline & 0.993 \\
\hline dk3 & $<---$ & Work dicipline & 0.536 \\
\hline $\mathrm{dk} 4$ & $<---$ & Work dicipline & 0.682 \\
\hline $\mathrm{dk} 5$ & $<---$ & Work dicipline & 0.771 \\
\hline ko1 & $<---$ & Organization performance & 0.638 \\
\hline ko2 & $<---$ & Organization performance & 0.689 \\
\hline ko3 & $<---$ & Organization performance & 0.598 \\
\hline ko4 & $<---$ & Organization performance & 0.692 \\
\hline ko5 & $<---$ & Organization performance & 0.907 \\
\hline ko6 & $<---$ & Organization performance & 0.580 \\
\hline ko7 & $<---$ & Organization performance & 0.547 \\
\hline ko8 & $<---$ & Organization performance & 0.750 \\
\hline ko9 & $<---$ & Organization performance & 0.658 \\
\hline ko10 & $<---$ & Organization performance & 0.687 \\
\hline
\end{tabular}

Source: Primary Data, 2020 (processed)

Based on table 1 above, it appears that all indicators included in the model have met the requirements for inclusion in the subsequent data processing. Before proceeding to the structural stage, the feasibility of the model will be seen first, this is because there is no single indicator that has a value of less than 0.5 . Testing the feasibility of the model is done by testing the model fit through goodness of fit.

From the description of the Goodness of fit Measurement Model above, the summary is as explained in Table 2.

Table 2. Goodness of Fit

\begin{tabular}{|l|l|l|l|}
\hline Goodness-of-Fit Index & Cut off Value & Hasil Analisis & Evaluasi Model \\
\hline Degree of Freedom (DF) & Positif $(+)$ & Positif $(+)$ & Baik \\
\hline$x^{2}($ Chi-Square $)$ & Diharapkankecil & 480.418 & Baik \\
\hline Signifikan Probability & $\geq 0.05$ & 0.051 & Baik \\
\hline CMIN/DF & $\leq 2.00$ & 1.641 & Baik \\
\hline GFI & $\geq 0.90$ & 0.948 & Baik \\
\hline AGFI & $\geq 0.90$ & .993 & Baik \\
\hline PGFI & $\geq 0.90$ & .961 & Baik \\
\hline NFI & $\geq 0.90$ & .957 & Baik \\
\hline TLI & $\geq 0.90$ & .981 & Baik \\
\hline CFI & $\geq 0.90$ & .929 & Baik \\
\hline PNFI & $0.60-0.90$ & 0.729 & Baik \\
\hline RMSEA & $0.05-0.08$ & 0.073 & Baik \\
\hline
\end{tabular}

Source: Primary Data, 2020 (processed) 
International Journal of Business Management and Economic Review

Vol. 3, No. 02; 2020

ISSN: 2581-4664

\section{Structural Equation Modeling Result}

The next analysis is a full model SEM analysis, after an analysis of the uni dimensionality level of the indicators forming latent variables was tested with confirmatory factor analysis. Analysis of the results of data processing at the full SEM model stage is carried out by conducting a suitability test and a statistical test. The results of data processing for the full SEM model analysis are shown in Figure 1.

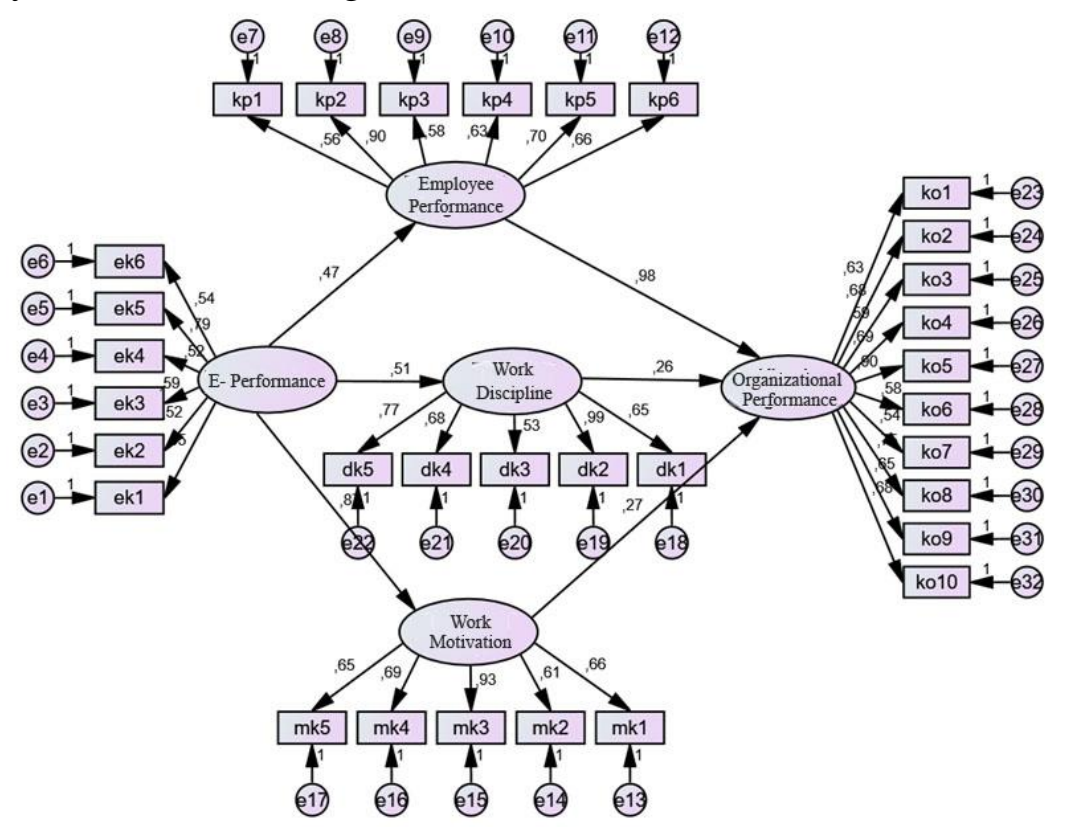

Figure 1. SEM Test Result

Testing the 6 hypotheses of this study was based on the value of the Critical Ratio (CR) of a causal relationship from the result of SEM processing as in table elow

Table3. Standardized Regression Weights

\begin{tabular}{|c|c|c|c|c|c|c|}
\hline & & Estimate & S.E. & C.R. & $\mathrm{P}$ & Label \\
\hline $\begin{array}{l}\text { Employee } \\
\text { performance }\end{array}$ & $<---$ E-performance & .472 & 0.080 & 9.733 & $* * *$ & Ha accepted \\
\hline Work dicipline & $<---$ E-performance & .874 & 0.067 & 7.367 & $* * *$ & Ha accepted \\
\hline Work motivation & $<---$ E-performance & .514 & 0.108 & 7.951 & $* * *$ & Ha accepted \\
\hline $\begin{array}{l}\text { Organization } \\
\text { performance }\end{array}$ & $<--\begin{array}{l}\text { Employee } \\
\text { performance }\end{array}$ & .983 & 0.103 & 8.235 & $* * *$ & Ha accepted \\
\hline $\begin{array}{l}\text { Organization } \\
\text { performance }\end{array}$ & <--- Work dicipline & .276 & 0.073 & 5.795 & $* * *$ & Ha accepted \\
\hline $\begin{array}{l}\text { Organization } \\
\text { performance }\end{array}$ & $<--\begin{array}{l}\text { Work } \\
\text { motivation }\end{array}$ & .268 & 0.089 & 8.763 & $* * *$ & Ha accepted \\
\hline
\end{tabular}

Source: Primary Data, 2020 (processed)

The effect of e-performance on employee performance shows a CR value9.733 and with 


\section{International Journal of Business Management and Economic Review}

Vol. 3, No. 02; 2020

ISSN: 2581-4664

a probability 0.003 . These two values meet the requirements for $\mathrm{H} 2$ acceptance, which are the CR value $9.733>1.97$ and a probability $<0.05$. Thus it figures that the e-performance implemented affects the performance of employees.

The effect of e-performance on employee discipline shows a CR value 7.367with a probability 0.007. Both values are eligible for $\mathrm{H} 1$ acceptance, that are the $\mathrm{CR}$ value 7.367> 1.97 and its probability $<0.05$. Thus it describes that e-performance affects employee discipline.

The effect of e-performance on employee work motivation shows a CR value 7.951with probability 0.009. Both values are eligible for $\mathrm{H} 3$ acceptance, that are the CR value7.951> 1.97 and its probability $<0.05$. Thus it reveals that e-performance implemented affects the employee work motivation.

The effect of employee performance on organizational performance shows a CR value 8.325 with its probability 0.019 . Both values meet the requirements for $\mathrm{H} 4$ acceptance, namely a CR value $8.325>1.97$ and its probability $<0.05$. Thus it explains that employee performance affects the performance of the Banda Aceh City Government.

The effect of work discipline on organizational performance shows a CR value of 5.795 and with its probability of 0,000 . Both values meet the requirements for $\mathrm{H} 5$ acceptance, namely a $\mathrm{CR}$ value 5.795> 1.97 and its probability $<0.05$. Thus it defines that work discipline will affect the performance of the Banda Aceh City Government.

The effect of work motivation on employee performance shows a CR value 8.763 and with its probability 0.000 . Both values are obtained to meet the requirements for $\mathrm{H} 6$ acceptance, namely a CR value $8.763>1.97$ and the probability $<0.05$. Thus it explains that work motivation will affect the performance of the Banda Aceh City Government.

\section{CONCLUSION}

The resultproves that e-performance affects employee performance,e-performance affects employee discipline, e-performance affects work motivation, employee performance affects organizational performance, work discipline will affectsorganizational performance, and work motivation affects organizational performance of the Banda Aceh Secretariat. These all findings prove the previous theories to be the update ones, and the model contributes to the realm of science and the practical implications, especially in the research object that is Banda Aceh Secretariat. The novelty originality lies in the integration of the causality theories from the previous, and its new object. The limitation resides in its scope and the variable amount.

It is important to note that the ANJAB feature on e-performance must illustrate the relationship between the main tasks and functions of each employee so that it is reaffirmed.Discipline also needs attention, especially with regard to sanctions or penalties given to employees who break the rules to be further improved.To improve the work motivation, what needs to be considered is that employees must work harder in order to give employees to occupy certain positions, especially by giving rewards to employees who are considered to be performing.

\section{REFERENCES}

Bastian, I. (2007) Sistem Akuntansi Sektor Publik. Ed. 2. Jakarta: Salemba Empat.

F. Hair Jr, J. et al. (2014) 'Partial least squares structural equation modeling (PLS-SEM) An emerging tool in business research', European Business Review. Emerald Group Publishing 
Vol. 3, No. 02; 2020

ISSN: 2581-4664

Limited, 26(2), pp. 106-121.

Harris, K. J., Harvey, P. and Kacmar, K. M. (2009) 'Do Social Stressors Impact Everyone Equally? An Examination of the Moderating Impact of Core Self-evaluations', Journal of Business and Psychology, 24(2), pp. 153-164.

Ilyas, W. B. (2011) Konflik dan Manajemen Konflik. Jakarta: Salemba Empat.

Mangkunegara, A. P. (2013) Manajemen Sumber Daya Manusia Perusahaan. Bandung: Remaja Rosdakarya.

Marzuki, Nasir and Sofyan (2018) 'Pengaruh Pembelajaran Organisasi, Konflik Peran Dan Budaya Organisasi Terhadap Kinerja Pegawai Serta Implikasinya Pada Kinerja Kanwil DJP Aceh', Jurnal Manajemen Pascasarjana Unsyiah, 1(1), pp. 1-10.

Miswar, E., Musnadi, S. and Mahdani (2015) 'Penerapan E-Kinerja Terhadap Peningkatan Disiplin Dan Motivasi Serta Implikasinya Pada Kinerja Pegawai Sekretariat Daerah Kota Banda Aceh', Jurnal Manajemen Pascasarjana Unsyiah, 1(1), pp. 1-10.

Money, J. D. (1996) Konsep Pengenbangan Organisasi Publik. Bandung: Sinar Baru Algesindo.

Oktavina, E., Nurdasila and Kesuma, T. M. (2018) Pengaruh Gaya Kepemimpinan, Motivasi Kerja Dan Komunikasi Terhadap Kepuasan Kerja Dan Dampaknya. Syiah Kuala University. Available at: etd.Unsyiah.ac.id.

Putri, K. E., Arfan, M. and Basri, H. (2014) 'Pengaruh Penerapan E-Kinerja Dan Penghargaan (Reward) Terhadap Kinerja Aparatur Pengelolaan Keuangan Di Lingkungan Pemerintahan Kota Banda Aceh', Jurnal Administrasi Akuntansi : Program Pascasarjana Unsyiah, 3(4), pp. 1-10.

Rivai, V. and Sagala, E. J. (2014) Manajemen Sumber Daya Manusia untuk Perusahaan: Dari Teori ke Praktik. 3rd edn. Jakarta: Rajawali Pers.

Robbins, S. P. and Judge, T. A. (2012) Organizational Behavior. 15th edn. Edited by S. Yagan. San Diego: Pearson.

Shiri, M., Akhavan, S. and Geramian, N. (2012) 'Anxiety Disorder and Its Types', in Olisah, V. (ed.) Essential Notes in Psychiatry. Croatia: InTech, p. 580.

Siagian, S. P. (2012) Teori Motivasi dan Aplikasinya. Jakarta: Rineka Cipta.

Soepangat, E. and Gaol, H. L. (1991) Pengantar Ilmu Keuangan Negara. Jakarta: Gramedia Pustaka Utama.

Surjadi (2009) Pengembangan Kinerja Pelayanan Publik. Bandung: Refika Aditama.

Swanburg, R. C., Ester, M. and Samba, S. (2000) Pengantar Kepemimpinan \& Manajemen Keperawatan Untuk Perawat Klinis. Jakarta: Penerbit Buku Kedokteran.

Toha, M. (2017) Analisis Pengaruh Profesionalisme, Kedisiplinan, Motivasi Kerja, Budaya Kerja Dan Komunikasi Terhadap Kinerja Pegawai Otoritas Jasa Keuangan. Institut Agama Islam Negeri (IAIN) Salatiga.

Wilson and Heyel, C. (1987) Handbook of modern office management and administrative services. New Jersey: Mc Graw Hill Inc.

Winardi, J. (2006) Teori Organisasi dan Pengorganisasian. Jakarta: Raja Grafindo Persada.

Wirawan (2007) Budaya dan Iklim Organisasi. Jakarta: Salemba Empat.

Wungu, J. and Brotoharsojo, H. (2003) Tingkatkan Kinerja Perusahaan Anda dengan Merit System. Jakarta: Raja Grafindo Persada. 